\title{
CORRESPONDENCE
}

\section{Proposed universal framework for more user-friendly author instructions}

\author{
Sylwia Ufnalska \\ EASE Council member, freelance science translator and editor, Poznań, Poland; sylwia.ufnalska@gmail.com \\ Alison Terry \\ Freelance copyeditor, Coimbra, Portugal, editorial@alisonterry.uk
}

DOI: $10.3897 /$ ese.2020.e53477

According to the Golden rules for scholarly journal editors ${ }_{2}{ }^{1}$ published in 2014 by the European Association of Science Editors (EASE), instructions for authors should be simple and easily understood. Unfortunately, it is still surprising how long it can take to find out journals' specific preferences, which can influence acceptance. Journals present this information in very different ways, sometimes across multiple web links, with some details out of date or contradictory.

We propose that journals include a simple table at the start of their instructions for authors, clearly displaying the essential information relating to manuscript preparation and submission. This would make it easy to locate each journal's specific requirements for manuscript structure, content, formatting, etc. Such a table could be also easily updated as journal preferences change, and increase the likelihood of submitted articles meeting the basic requirements (eg word count, number of keywords, format of tables and figures).

The example presented here includes text in the right-hand column to illustrate how the table could be completed, but it can be adapted to suit individual publications. For example, journal editors might indicate "not applicable" for some elements, or add rows with new types of information. Such a "quick check" table is already in use for the EASE journal, European Science Editing. ${ }^{2}$

We hope this initiative will save time for everyone involved in the process of drafting, editing and submitting an article - as well as for the journal's editorial team, since manuscripts will then be more likely to meet submission criteria; so please help us spread the word!

\section{Acknowledgements}

We are very grateful to EASE members who provided useful comments on the draft of the table: Eva Baranyiová, Ksenija Baždarić, Paola de Castro, Yateendra Joshi, Joan Marsh, Bahar Mehmani, Duncan Nicholas, Pentti Nieminen, Mandy Payne, Arjan Polderman, Pippa Smart, and Jadranka Stojanovski.

\section{References}

1 Ufnalska SB, Polderman AKS. Golden rules for scholarly journal editors. European Science Editing 2014;40(3):65. https://ease.org.uk/publications/ ease-toolkit-journal-editors/golden-rules-scholarly-journal-editors

2 Quick check for submissions. European Science Editing. https://ese. arphahub.com/about\#Quickcheckforsubmissions (accessed 21 April 2020)

3 EASE Guidelines for Authors and Translators of Scientific Articles to be Published in English. European Association of Science Editors. https:// ease.org.uk/publications/author-guidelines-authors-and-translators/ (accessed 21 April 2020)

4 ORCID. https://orcid.org/ (accessed 21 April 2020)

5 Research Organization Registry https://ror.community/ (accessed 21 April 2020)

6 Funder Registry. Crossref. https://www.crossref.org/services/funderregistry/ (accessed 21 April 2020)

7 CRediT - Contributor Roles Taxonomy. CASRAI. https://www.casrai.org/ credit.html (accessed 21 April 2020)

8 EASE Ethics Checklist for Authors. European Association of Science Editors. https://ease.org.uk/publications/ease-checklist/ (accessed 21 April 2020)

9 EASE Form for Authors' Contributions and Conflict of Interest Disclosure. European Association of Science Editors. https://www.ease.org.uk/ wp-content/uploads/ease_form_0.pdf (accessed 21 April 2020)

10 Conflicts of Interest. International Committee of Medical Journal Editors. http://www.icmje.org/conflicts-of-interest/ (accessed 21 April 2020) 


\section{BASIC INFORMATION FOR MANUSCRIPT SUBMISSION}

\begin{tabular}{|c|c|}
\hline GENERAL GUIDELINES & $\begin{array}{l}\text { Manuscripts should be COMPLETE, CONCISE and } \\
\text { CLEAR (see EASE Guidelines for Authors and } \\
\underline{\text { Translators }^{3}} \text {, available in many languages). Follow the } \\
\text { appropriate reporting guideline, if applicable }\end{array}$ \\
\hline \multicolumn{2}{|l|}{ WORD LIMITS } \\
\hline Body text & $\leq \mathrm{X}$ words (justified exceptions allowed) \\
\hline Abstract & $\begin{array}{l}\leq X \text { words; structured for original research } \\
\text { (BACKGROUND, OBJECTIVES, METHODS, RESULTS, } \\
\text { CONCLUSIONS), unstructured for review articles }\end{array}$ \\
\hline Keywords & $\begin{array}{l}\leq X \text { terms, listed alphabetically, singular, separated } \\
\text { with semicolons; lowercase except proper names; } \\
\text { avoid abbreviations }\end{array}$ \\
\hline Highlights (below the abstract) & $\begin{array}{l}X-Y \text { bullet points ( } \leq X \text { words each, describing the study } \\
\text { in lay terms) }\end{array}$ \\
\hline Tables/figures & $\begin{array}{l}\leq X \text { tables/figures in total. Their description (captions, } \\
\text { values, units, etc.) should be consistent and } \\
\text { informative, with all abbreviations explained }\end{array}$ \\
\hline \multicolumn{2}{|c|}{ TITLE PAGE INFORMATION (elements to include, format required) } \\
\hline Title & $\begin{array}{l}\leq X \text { characters, with a description of the study type, if } \\
\text { relevant (eg a review) }\end{array}$ \\
\hline Short running title & $\leq \mathrm{X}$ characters \\
\hline Author names & Full name: given name(s) first, family name last \\
\hline Affiliation info required & $\begin{array}{l}\text { Department, institution, city, country, email (indicated } \\
\text { with superscript a, b, c; each on a new line) }\end{array}$ \\
\hline Corresponding author contact details & Indicate with an asterisk, supply tel. \# \\
\hline Persistent identifiers of author(s), etc. & $\begin{array}{l}\underline{\mathrm{ORCID} \mathrm{iD}}(s)^{4}, \text { identifiers of } \underline{\text { research organization }}(\mathrm{s})^{5}, \\
\underline{\text { funder }(s)^{6}} \text { and research project(s), if applicable }\end{array}$ \\
\hline
\end{tabular}

\section{STRUCTURE OF BODY TEXT, END MATTER, REFERENCES}

Typical/mandatory headings

Subheadings

Specific wording required for any section
Introduction (background and objectives), Methods, Results, Discussion (with a concluding paragraph) $\leq \mathrm{X}$ levels of subheadings, not numbered Methods section must include usual ethical approval for human and animal studies (Helsinki/Institutional Review Board compliance, informed consent) and subsection "Statistical analysis", identifying the variables and methods used

Identify authors by initials in the authorship contributions section (consider using $\underline{\mathrm{CRediT}^{7} \text { ) }}$ Not limited (with DOIs, URN, PURL, etc. if applicable) $X$ style; for more details and examples, see $\langle U R L>$. Endnote style can be downloaded here $<U R L>$. Make sure that each citation is complete and accurate 
FORMATTING (links to any style guides/templates and samples: fonts, margins, tables, figures)

Spelling

General style

\section{SUBMISSION NOTES}

Cover letter required? Specific content?

Links to all required author forms: needed at submission or after acceptance? Signed by all authors or by submitting author?

Proposed reviewers: optional/mandatory? How many? What details are required?

Tables: separate files?

Figures: embedded in the manuscript or supplied separately as high-resolution image files? What formats are preferred? Supplementary files?

Fees for open access, colour, etc.?

UK or US, if consistent

- Numbers $\geq 2$ as numerals (for exceptions, see EASE Guidelines ${ }^{3}$ )

- Statistics: $p \leq 0.001, n=\# \#(95 \% \mathrm{Cl} \# \#$,\#)

Not required but text field in the online submission system allows for comments to the editorial office

- EASE Ethics Checklist ${ }^{8}$ signed by corresponding author at submission

- EASE Form $^{9}$ or ICMJE COI forms ${ }^{10}$ signed by all authors at submission

OPTIONAL: suggest/oppose up to 3 potential reviewers (full name, email, institution). Consider diverse peer reviewers in terms of gender, ethnicity and geographical distribution Include at the end of the manuscript (separate pages) For initial submission, figures can be embedded in the manuscript. If it is accepted, high-resolution files (EPS/TIFF/RAW) will be required Upload any supporting data or other required files (eg ethics approval) for review

Publication fee $\mathrm{X}$. Colour free online but $\mathrm{X}$ per figure for print

\section{JOURNAL POLICIES, ETC.}

Publication model*

Open access, licence $X$; fee structure: $<U R L>$

Preprint policy

Publication on any preprint server is acceptable

Data sharing

Recommended repositories: ...

Clinical trials must include a data sharing statement; other studies may also do so

Peer review**

Time to first decision about whether to send for peer review: about $X$ days. External, double-blind review usually by $X$ reviewers, taking about $X$ days/weeks. Editor(s) make(s) the final decision

Manuscript acceptance rate About X\%

* Publication models: subscription, hybrid (open access optional for a fee) or open access

** Peer review systems - e.g. open, single-blind, double-blind, triple-bind 